\title{
Advancing knowledge about restricted irrigation strategies on commercial peach plantation under Mediterranean condition
}

\author{
Aziz Abouabdillah ${ }^{1 *}$, Soukaina Radi $^{1}$, Adil Asfers ${ }^{2}$, Youssef Brouziyne $^{3}$,Omnia El Bergui ${ }^{1,4}$, \\ Mohamed Bourioug ${ }^{1}$, Fouad Amlal ${ }^{5}$, and Rachid Bouabid ${ }^{1}$ \\ ${ }^{1}$ Ecole Nationale d'Agriculture de Meknès, Meknès, Morocco \\ ${ }^{2}$ Agricultural Training and Research Center, Providence Vertecompany,LOUATA farm, Séfrou, \\ Morocco \\ ${ }^{3}$ Mohammed VI Polytechnic University, International Water Research Institute, Benguerir, Morocco \\ ${ }^{4}$ Institut Agronomique et vétérinaire Hassan II, Rabat, Morocco \\ ${ }^{5}$ Université Chouaib Doukkali Avenue Jabran Khalil Jabran, B.P 299-24000, El jadida Grand- \\ Casablanca, Maroc
}

\begin{abstract}
This study was conducted to investigate the effects of different restricted irrigation strategies on peach trees. Sustainable and regulated deficit irrigation treatments were applied during the 2018/2019 production season in a commercial plot of "Bénédicte" variety located at the Atlas Mountain's region of Morocco. Five different treatments were tested: T1, $\mathrm{T} 2$ and $\mathrm{T} 3$ with an application of respectively $125 \%$ (over-irrigation), $100 \%$ (control) and 75\% (deficit-irrigation) of Crop Water Requirement (CWR) throughout the whole crop cycle; These treatments were classified under Sustainable Deficit Irrigation treatments (SDI). Regulated Deficit Irrigation treatments (RDI) comprising of treatments $\mathrm{T} 4$, and $\mathrm{T} 5$ which correspond respectively to applications of 75\% ETc and 50\% ETc during the pit hardening stage $(\mathrm{PH})$, and $100 \%$ ETc during the rest of the cycle. The results showed that deficient irrigation treatments had no effect on vegetative growth parameters.A downward trend in average fruit weight and size at harvest was observed in the $\mathrm{T} 3$ treatment. A significant increase in sugar content was observed in T3 and T5 compared to the control T2. With regard to biochemical parameters, the deficient treatment (T5) recorded the highest proline content in response to water stress, followed by $\mathrm{T} 3$ and $\mathrm{T} 4$. Therewas no significant difference between the crop yields under SDI and RDI treatments, but T4 produced arelatively higher yield of $47 \mathrm{~T} /$ Haamong the treatments. Thisled to the water use efficiency (WUE) performance ranking: T3 with $10.63 \mathrm{~kg} / \mathrm{m}^{3}$, T4 $(75 \% \mathrm{PH})$ was in second place with a WUE of $9.6 \mathrm{~kg} / \mathrm{m}^{3}$, finally T5 with an efficiency of 9.35 $\mathrm{kg} / \mathrm{m}^{3}$.
\end{abstract}

*Corresponding author:aziz.abouabdillah@gmail.com 


\section{Introduction}

In many parts of the Mediterranean region, water is a major constraint for crop production, given the dramatic increase in demand for this element on one hand and the consequences of climate change on the other hand. Indeed, by 2050, rainfall amounts in North African countries would be reduced by 20 to $50 \%$ compared to current average annual values [1].Globally, irrigation consumes around $85 \%$ of available freshwater[2]; and this ratio goes up to $93 \%$ in Morocco[3]. Due to various agricultural development plans, irrigated fruit trees in Morocco have been developed considerably in recent years and becameone of the largest consumers of irrigation water; this raises questions about the sustainability of fruit tree crops in such water stressed country. Therefore, and under this context, the improvement of the water use efficiency is crucial.Thismight be achievedthrough the application of adequate irrigation strategies, such asdeficit irrigation [4].

Despite of the large number of studies reported on deficit irrigation strategies, there is still significant knowledge to gain on the response of tree crops (especiallypeachestrees) to restricted irrigation scheme under the Mediterranean climate. Among the various attempts to explore this field, there have been some works on the improvement of water use efficiency in peaches trees using deficit irrigation strategies in Lleida area in Northern Spain[5], The exploration of root dynamics of peach trees under partial rootzone drying and continuous deficit irrigation in Murcia region (Spain)[6]; other researchers focused more on physiological response of peaches tree submitted to deficit irrigation strategies in Tunisia[7]and in France[8]. As per the very few works on the consequences of restrictive irrigation management on both productivity and fruit quality of peaches trees in the Mediterranean area, Faci et al., [9], tried to monitor a set of yield and fruit quality parameters while applying different irrigation schemes in Ebro Valley (Spain), and they proved that saving irrigation water is possible without affecting productivity and fruit quality under the experiment conditions.

In any regulated deficit irrigation management strategy, the selection of the growth stage (s) where water restriction will be applied is of crucial importance.Most specialists agree that that pit hardening (PH) stage (Stage II) is an adequate period for the application of deficit irrigation (DI)on peaches trees [10]. In addition to water saving, DI at stage II might improve fruit quality too $[11,12,13]$. The improvement in fruit quality was mainly expressed as increase of fruit soluble solids (FSS) content. As a result, a consumer panel indicates an increased preference for fruits grown under restricted irrigation [14]. Moreover, applying deficit Irrigation at stage II reduces fruit drop phenomenon at maturity $[11,13]$ and could decrease shoot growth[11, 12, 13]. As peryield, the application of regulated deficit irrigation (RDI) at the pit hardening ( $\mathrm{PH})$ stage does not affect the final yield according to some authors[11, 13, 15]. However, in other studies, a significant reduction in yield and fruit size at harvesting stage has been recorded[12, 16]. In addition, for sustainable deficit irrigation (SDI) and since water stress affects all stages of fruit development, the effect on production is most apparent through the reduction in size, fruit weight and yield[11, 17, 18, 19]. This paper discusses the effect of sustainable deficit irrigation (SDI) and regulated deficit irrigation (RDI) on peach trees; The specificobjective of this study is to refine the crop coefficient Kc model of peaches published in FAO-Bulletin 56 to the real conditions of Atlas Mountainsarea in Morocco in order to achieveoptimal production in terms of both quantity and quality standards. 


\section{Materials and methods}

\subsection{Experimental trial}

This research was carried out during the 2018-2019 growing season on a 17 years old peach cultivar 'Benedicte'. The trial was set up at the orchard: "LOUATA", located in the NorthEast of the Middle Atlas Mountains chain, inMorocco; the growing area is surrounded bythe two cites Fez and Séfrou, at an altitude varying from 400 to $770 \mathrm{~m}$ above meansea level. This region has a warm Mediterranean climate with dry summers according to the koppen-Geiger classification. The mean annual rainfall and temperature were respectively $502 \mathrm{~mm}$ and $15.9{ }^{\circ} \mathrm{C}$ based on 1982 to 2012 climate dataset. The trees were planted in 2003 at $5 \mathrm{~m}$ row spacing and $3 \mathrm{~m}$ tree spacing within the rows. The trees were grafted onto GF667 rootstock and conducted on goblet. The soil has the following textural composition: $50.0 \%$ clay, $32.3 \%$ silt and $18.1 \%$ sand over a depth of $40 \mathrm{~cm}$. Thewater content at the field capacity (FC) was estimated to $42.1 \%$ and a wilting point moisture content (WP) of $2.96 \%$,therefore water retention capacity is around $125 \mathrm{~mm}$ per $1 \mathrm{~m}$ depth. During the experiment trial, the sum of the reference evapotranspiration ET0 during the irrigation season (from fruit set to harvest) was about $520 \mathrm{~mm}$ while the cumulative precipitation $(\mathrm{mm})$ was $36.2 \mathrm{~mm}$. Precipitation was taken into account in the estimation of irrigation water for each treatment. Apart from the irrigation protocols described below, the experimental plot was managed in accordance with the standard farm practices including fertilization, pest management and weed control. This means that all the studied treatments havereceived the same amounts ofinputs except for irrigation. Thinning and winter pruning were also carried out in the same manner for all treatments. The experimental plot was equipped with a localized drip irrigation system. Each planting line had two polyethylene lateral pipes, equipped with integrated drippers evenly spaced by $60 \mathrm{~cm}$ on the lateral and delivering 2.2 liters per hour of water.

\subsection{Irrigation treatments}

The table 1 represents the different irrigation treatments subject to investigation in this study. The tested five treatments are:T1 the over-estimate of water crop requirement $(125 \%$ ETc), T2 representing the control (100\% Crop evapotranspiration ETc), T3 the sustainable deficit irrigation (SDI) treatment $(75 \%$ ETc) that was applied over the whole fruit development stage from early March to late July, and the two regulated deficit irrigation (RDI) treatments $\mathrm{T} 4$ and T5 where respectively $75 \%$ and $50 \%$ ETc have been applied during the phase II of fruit development (pit hardening PH) and $100 \%$ ETc was applied during the rest of the cycle.

The calculation of the irrigation water requirements is based on a water balance, which expresses the difference between the crop's water requirements and the water input from natural sources, given by the formula:

$$
G W R=\left(\frac{K c \times E T_{0}}{I E \times U C}\right)-E_{r}
$$

With, GWR: Gross Irrigation water requirement (mm); Er: Effective rainfall (mm), also called useful rainfall, calculated by removing at total rainfall, the losses by runoff or deep percolation (70\%); Kc: Crop coefficient of the peach proposed in FAO Bulletin 56[20] (Kc 
in $=0.55$ during flowering and fruiting; $\mathrm{Kc}$ mid $=0.9$ at development and $\mathrm{Kc}$ end $=0.65$ during ripening); IE is the irrigation efficiency ( 0.9 since the irrigation network was new), and UC, uniformity coefficient was calculated 0.93 ; and ET0 $(\mathrm{mm})$ is the reference daily evapotranspiration calculated by the modified Penman-Montheinth formula[21]. The estimation of ET0 was based on climate parameters obtained from the weather station installed within the trial orchard.

Table 1.Description of the different irrigation treatments subject to investigation in the study.

\begin{tabular}{|l|c|c|}
\hline \multicolumn{1}{|c|}{ Treatment type } & $\begin{array}{c}\text { Treatment } \\
\text { name }\end{array}$ & \multicolumn{1}{c|}{ Description } \\
\hline $\begin{array}{l}\text { Over-irrigated } \\
\text { treatment }\end{array}$ & $\mathrm{T} 1(125 \%)$ & $\begin{array}{c}\text { supply of 125\% of the crop's water } \\
\text { requirements throughout the growth cycle }\end{array}$ \\
\hline Control treatment & $\mathrm{T} 2(100 \%)$ & $\begin{array}{c}\text { supply of the exact needs of the crop (100\% } \\
\text { ETc) during the whole growth cycle }\end{array}$ \\
\hline $\begin{array}{l}\text { Sustainable Deficit } \\
\text { Irrigation treatment }\end{array}$ & $\mathrm{T} 3(75 \%)$ & $\begin{array}{c}\text { supply of 75\% of the crop's water requirements } \\
\text { throughout the growth cycle }\end{array}$ \\
\hline $\begin{array}{l}\text { Regulated Deficit } \\
\text { Irrigation treatment }\end{array}$ & $\mathrm{T} 4(75 \% \mathrm{PH})$ & $\begin{array}{c}\text { supply of } 75 \% \text { of the crop's water needs during } \\
\text { the stage of pit hardening and 100\% of the } \\
\text { needs during the rest of the growth cycle. }\end{array}$ \\
\hline $\begin{array}{l}\text { Regulated Deficit } \\
\text { Irrigation treatment }\end{array}$ & $\mathrm{T} 5(50 \% \mathrm{PH})$ & $\begin{array}{c}\text { supply of 50\% of the crop's water needs during } \\
\text { the stage of pit hardening and 100\% of the } \\
\text { needs during the rest of the growth cycle. }\end{array}$ \\
\hline
\end{tabular}

\subsection{Experimental design}

A randomized full block design was used in this trial with four block repetitions. Each replicated block hostedall the five treatments. Each treatment grouped 4 trees in the same block; three of them with the same trunk diameter were selected to measure parameters while the others were considered as guard trees.

\subsection{Measured parameters}

Three trees per replicate (12 trees per treatment) were selected for monitoring growth, yield and quality parameters. Trees were selected based on trunk diameter to reducevariability amongtrees.

\subsubsection{Plant growth parameters}

The growth of mixed twigs was monitoredby measuring the length and basal diameter of the twigs. On four twigs per tree, distributed over the four cardinal points, three measurements per parameter were performedfrom the cell multiplication stage to harvest. Measurements were carried outusing a decameter for the length $(\mathrm{cm})$ and a precision caliper for the basal diameter ( $\mathrm{mm}$ ) of the twigs. Measurements were made once every 30 days. To assess the effect of the water regime on the growth of fruiting structures in the following year, the evolution of the length of young shoots was monitored on four shoots 
per tree at a rate of one shoot per orientation. This parameter was measured once every 15 days.

\subsubsection{Production Parameters}

Considering the feature of at maturity' fruit fall of the studied variety, the number of fruits was calculated on fourbranches/tree after thinning till the last day before harvesting. In order to determine fruit growth rate for each treatment, weekly monitoring of equatorial and longitudinal diameters was carried out on fourfruits per tree marked at fruit set stage on all the 60 trees. Fruits were equally distributed over the four orientations of the tree. The final fruit diameter was also measured after harvesting on a sample of 72 fruits/block using a precision caliper. On the same sample, fruitweight was measured using a precision balance. Harvest was carried out over 4 passes. In addition, weighing of the whole production was carried out at harvest for the 60 trees of the trial, and the average yield was then calculated for each treatment. The yield evaluation was based on the sum of the productions of the fourharvesting passes.

\subsubsection{Fruit quality parameters}

Three key fruit quality parameters were selected to be monitored in this experiment:

-Sugar content ( $\left.{ }^{\circ} \mathrm{Brix}\right)$ : on 72 fruits/block, the soluble solids content $\left({ }^{\circ} \mathrm{Brix}\right)$ was measured using a digital refractometer.

-Firmness: the firmness $\left(\mathrm{kg} / \mathrm{cm}^{2}\right)$ of the fruit was measured by a penetrometer on both sides of the fruit. The measurements were performedon the same sample used for the sugar content measurements.

-Acidity of the fruit: to measure the acidity of the fruit ( $\mathrm{g}$ of malic acid/L), $10 \mathrm{ml}$ of peach juice is mixed with $50 \mathrm{ml}$ of distilled water and 3 drops of phenolphthalein. The titration was then carried out by slowly pouring in the $0.1 \mathrm{~N} \mathrm{NaOH}$ solution until the juice/water mixture change from colorless to pink. The titratable acidity is then determined by multiplying the volume of added sodium hydroxide $(0.1 \mathrm{~N} \mathrm{NaOH})$ by the coefficient 0.67 (factor corresponding to the dominant acid in peach juice which is malic acid).

\subsubsection{Biochemical parameters}

The extraction and determination of proline was carried out according to the method described by [22]. $500 \mathrm{mg}$ of leaf samples are ground in $10 \mathrm{ml}$ of $3 \%$ Sulfosalicylic acid solution and the extract is then filtered through Whatman filter paper. Then $1 \mathrm{ml}$ extract is taken to which $1 \mathrm{ml}$ acetic acid $(\mathrm{CH} 3 \mathrm{COOH}), 25 \mathrm{mg}$ ninhydrin and $1 \mathrm{ml}$ mixture $(12 \mathrm{ml}$ distilled water, $30 \mathrm{ml}$ acetic acid and $8 \mathrm{ml}$ Ortho-phosphoric acid) are added. The tubes are incubated for $30 \mathrm{~min}$ at 100 degrees in a water bath. They gradually turn red. After cooling, $4 \mathrm{ml}$ Toluene is added to each tube. After stirring two phases are formed: the upper one containing proline is recovered and finally the optical density is determined by a spectrophotometer at wavelength $528 \mathrm{~nm}$. The concentration of proline in the plant leaves is determined by referring to a standard straight line prepared from a standard range of proline. 


\subsubsection{Water productivity}

Agronomic water use efficiency (or water productivity) is an important index that measures quantity produced from each cubic meter of consumed water for each treatment. The calculation formula is as follows: WUE $=$ Production $(\mathrm{kg}) /$ quantity of water applied (m3).

\subsection{Statistical analysis}

The results were analyzed in SPSS and Microsoft Office Excel programs using an analysis of unidirectional variance (ANOVA) followed by the Student Newman and Keuls (SNK) test used to compare means at the 5\% threshold.

\section{Results}

\subsection{Vegetative growth parameters}

\subsubsection{Mixed twig evolution}

In order to assess the effect of RDI and SDI on the growth of mixed twigs, the development of these structures was monitored on the basis of one observation per month. The measurements involved the length and basal diameter evolution of the mixed twigs.

Concerning the SDI (fig $1 \& 2$ ), the first measurement of twig elongation carried out in 55 days after flowering (cell division stage) and after 13 days of irrigation according to the experimental protocol, showed that T1 treatment $(125 \%)$ in the first place with $62.72 \mathrm{~cm}$ in length, followed by T2 $(100 \%)$ with $61.01 \mathrm{~cm}$ and finally T3 with an average length of $59.67 \mathrm{~cm}$. Two months later, T1 showed a length increment of $9.75 \mathrm{~cm}$, T2 showed 11.5 $\mathrm{cm}$ longer and T3 has increased its average length by $9.53 \mathrm{~cm}$. However, these elongation differences are not statistically significant, which makes it possible to say that a $25 \%$ excess or restriction in water supply compared to requirements does not affect the growth of mixed twigs in terms of length.Similarly, for basal diameter, the analysis of variance did not show any significant difference between $\mathrm{T} 1(125 \% \mathrm{ETc})$; T2 $(100 \% \mathrm{ETc})$ and $\mathrm{T} 3(75 \% \mathrm{ETc})$. Furthermore, between 55 and 115 days after flowering, the basal diameter of mixed twigs of T1 (125\%) revealed an increase of $1.30 \mathrm{~mm}$, followed by T2 (100\%) with $1.08 \mathrm{~mm}$ longer and finally T3 (75\%) with $0.93 \mathrm{~mm}$ increase.

As for the RDI (fig 3 and 4), no significant difference between the T2 control and the RDI treatments T4 (75\% PH) and T5 (50\% PH) was revealed, neither for the length of the mixed twigs nor for their basal diameter evolution. Furthermore, the mixed twig growth difference between T5 and the control was about $1.09 \mathrm{~cm}$ less than T2 in terms of length and $0.07 \mathrm{~mm}$ in terms of basal diameter. On the other hand, T4 showed higher growth deviations from the control T2, $2.16 \mathrm{~cm}$ in lengthand $0.24 \mathrm{~mm}$ in basal diameter. 


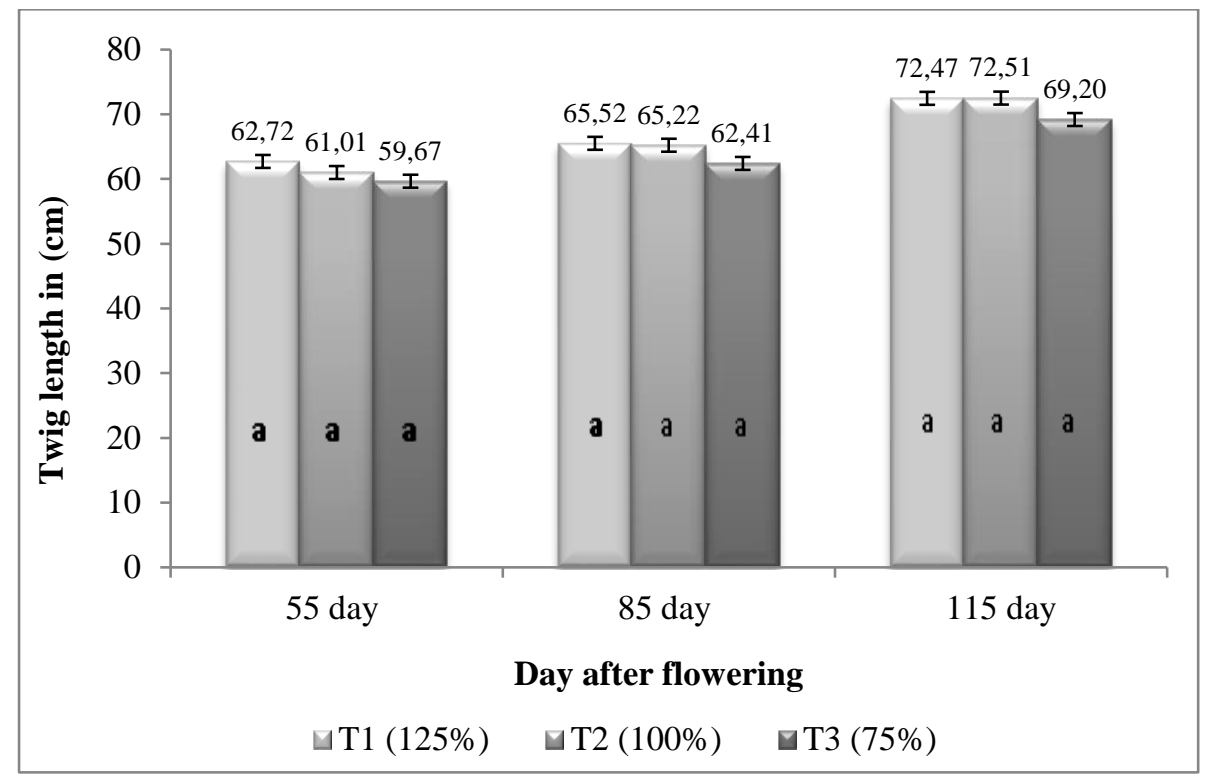

Fig. 1. Effect of Sustainable Deficit Irrigation (SDI) on the mixed twigs length during threemeasurements at 55 day; 85 day \& 115 day after flowering. The lines represent the standard deviation. The treatments are described in section 2.2. The different letters indicate significant differences according to the SNK test at $\mathrm{P} \leq 0.05$

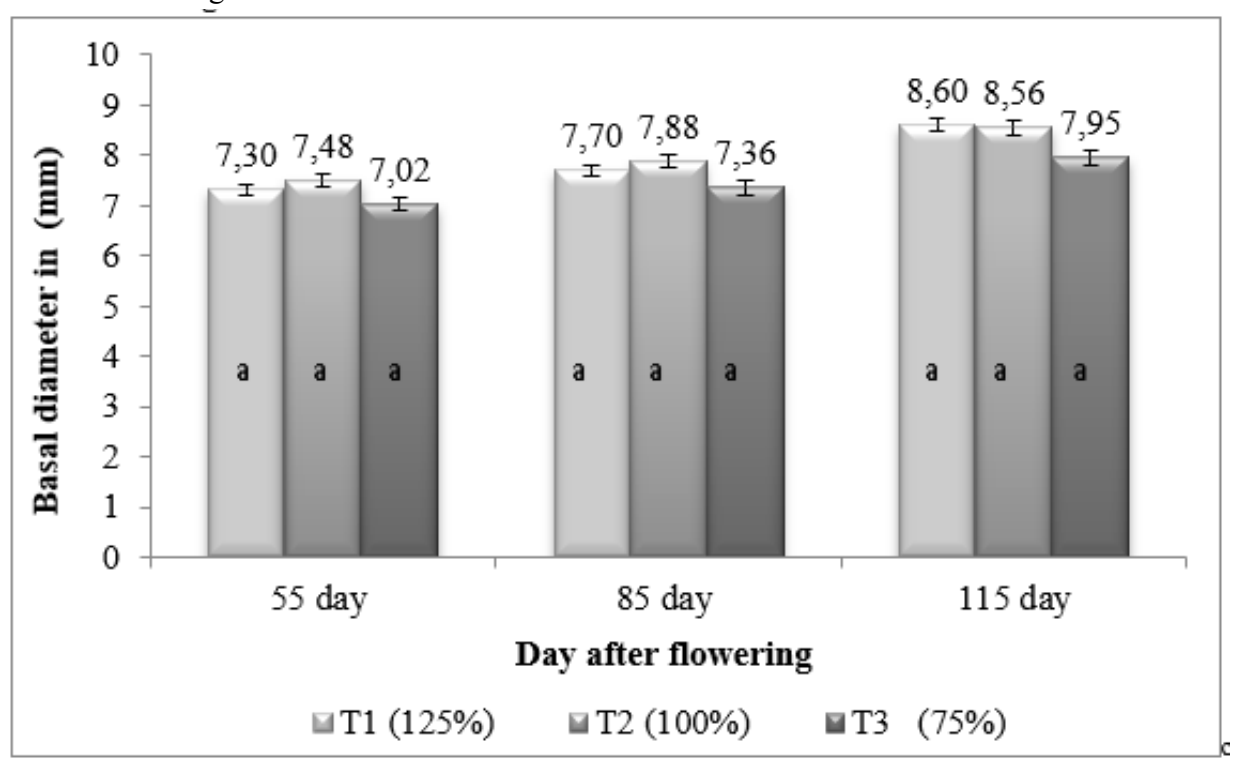

Fig. 2. Effect of Sustainable Deficit Irrigation (SDI) on the evolution of the basal diameter of mixed twigs during threemeasurements at 55 day; 85 day \& 115 day after flowering. The lines represent the standard deviation. The treatments are described in section 2.2. The different letters indicate significant differences according to the SNK test at $\mathrm{P} \leq 0.05$ 


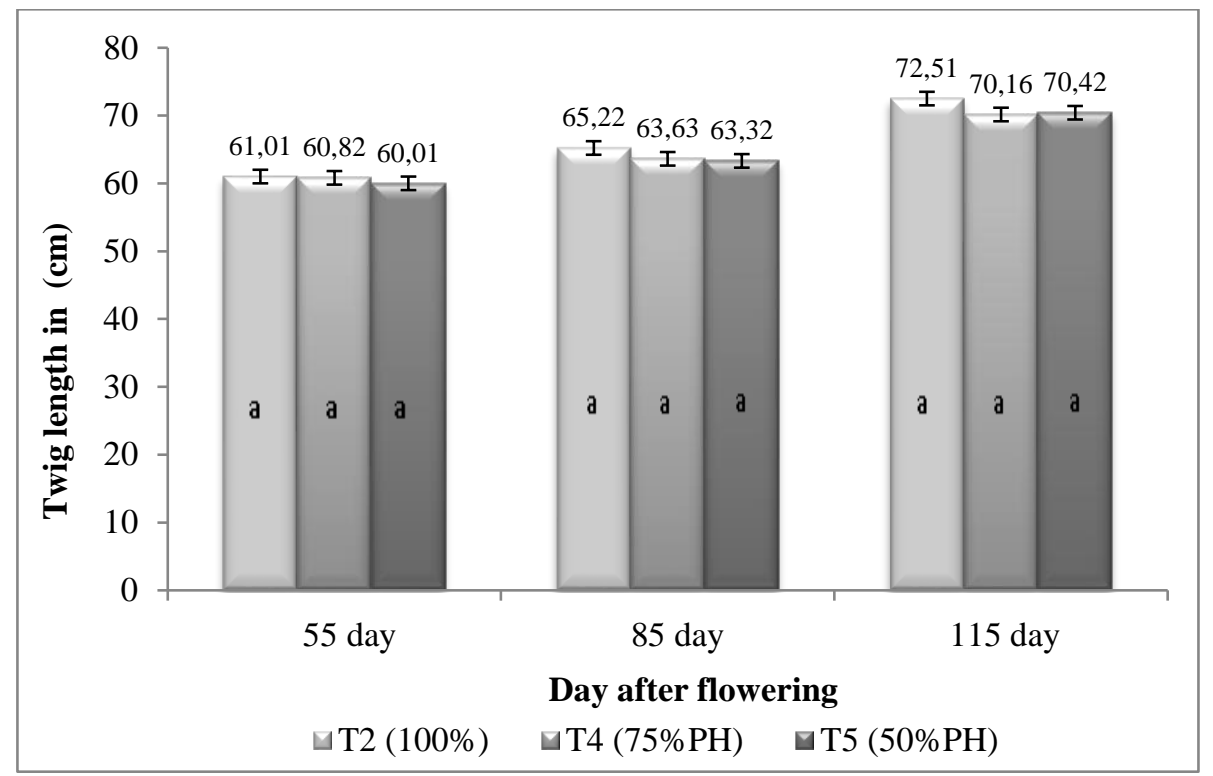

Fig. 3. Effect of Regulated Deficit Irrigation (RDI) on the mixed twigs length during threemeasurements at 55 day; 85 day \& 115 day after flowering. The lines represent the standard deviation. The treatments are described in section 2.2. The different letters indicate significant differences according to the SNK test at $\mathrm{P} \leq 0.05$.

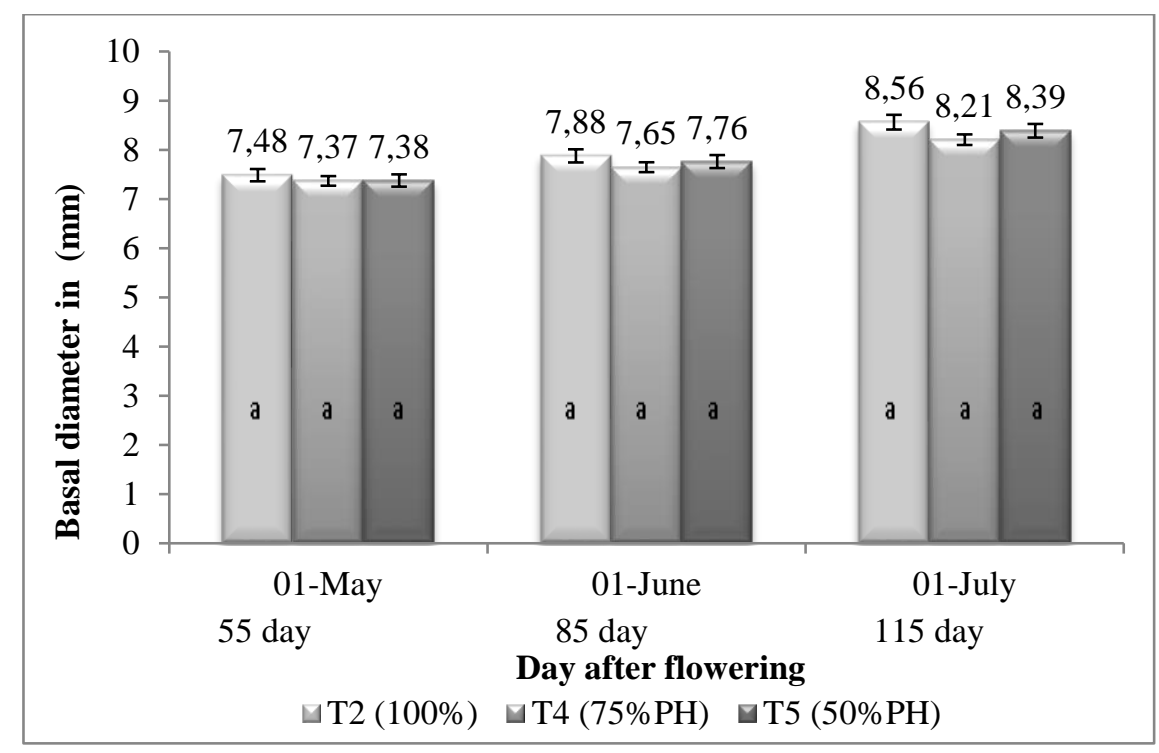

Fig. 4. Effect of Regulated Deficit Irrigation (RDI) on the evolution of the basal diameter of mixed twigs during threemeasurements at 55 day; 85 day \& 115 day after flowering. The lines represent the standard deviation. The treatments are described in section 2.2. The different letters indicate significant differences according to the SNK test at $\mathrm{P} \leq 0.05$. 


\subsubsection{Shoot elongation}

For peaches, the young shoots are the structures that bear the fruit for the following year; hence the importance of monitoring their evolution and highlighting the effect of the water regime on the elongation of these structures. Indeed, 4 measurements were taken every 15 days to monitorthe length of these structures. Regarding the SDI, statistical analysis did not show any significant effect of irrigation dose on the elongation of the young shoots (fig 5). Furthermore, starting from $0 \mathrm{~cm}$ length in the flowering stage for all treatments (T1; T2 and T3), the T2 control was able to reach an average length of $19.11 \mathrm{~cm}$ by 115 days after flowering (fruit swelling stage), followed by $\mathrm{T} 1$ with $17.01 \mathrm{~cm}$ as average length and finally T3 with $14.58 \mathrm{~cm}$ as average length. A presentation of the growth rate under the different treatments during this periodmakes it possible to separate between two phases, a first one going from cell multiplication to mid-swelling, and a second one lying between late swelling and maturity. As for the first period, the three treatments T1; T2 and T3 did not show any significant difference between each other in terms of elongation rate of the young shoots; it is only from mid-swelling (second period) that the difference between the growth rate of shoots in the three treatments begins to appear, putting on the one hand $\mathrm{T} 2$ treatment with the highest elongation rate $0.42 \mathrm{~cm} /$ day and on the other hand T1 and T3 with lower growth rates 0.14 and $0.10 \mathrm{~cm} /$ day respectively. No significant difference was observed between $\mathrm{T} 1$ and $\mathrm{T} 3$ in growth rate. However, these differences in elongation rate did not show any significant difference between the three treatments T1, T2 and T3 in final shoot length.

For RDI, there was no significant difference in shoot length between the T2 control; T4 (75\% PH) and T5 (50\% PH) (fig 6). Indeed, T2 recorded a shoot length of $19.11 \mathrm{~cm}$ on 01 July, which is $3.11 \mathrm{~cm}$ longer than T4 and $4.4 \mathrm{~cm}$ longer than T5. For the elongation rate, it should be noted that no significant difference between the T2; T4 and T5 was recorded, except for the late growth period when shoot growth in T2 was faster than in T4 and T5.

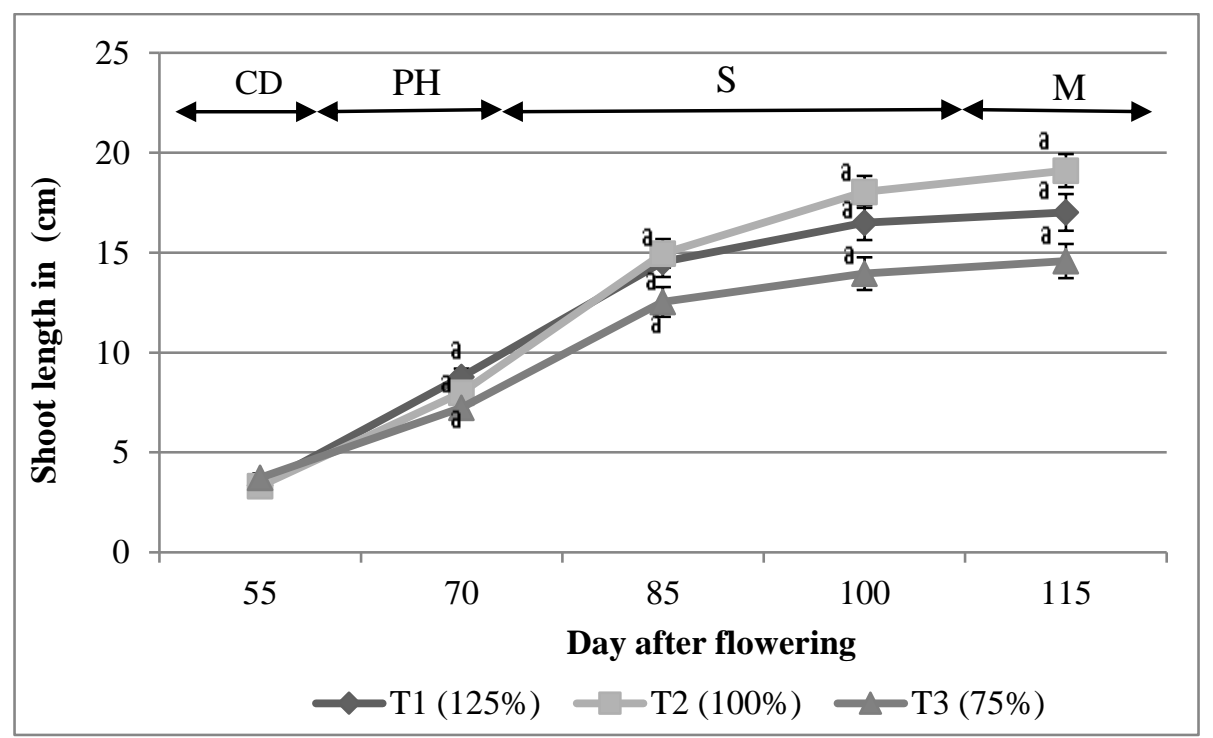

Fig. 5. Effect of Sustainable Deficit Irrigation (SDI) on the shoot length during fivemeasurements at $55 ; 70 ; 85 ; 100 \& 115$ days after flowering. The lines represent the standard deviation. The treatments are described in section 2.2.CD: cell division stage; PH: pit hardening stage; $\mathrm{S}$ : swelling fruit stage; 
M: maturity. The different letters indicate significant differences in the corresponding date, according to the SNK test at $\mathrm{P} \leq 0.05$.

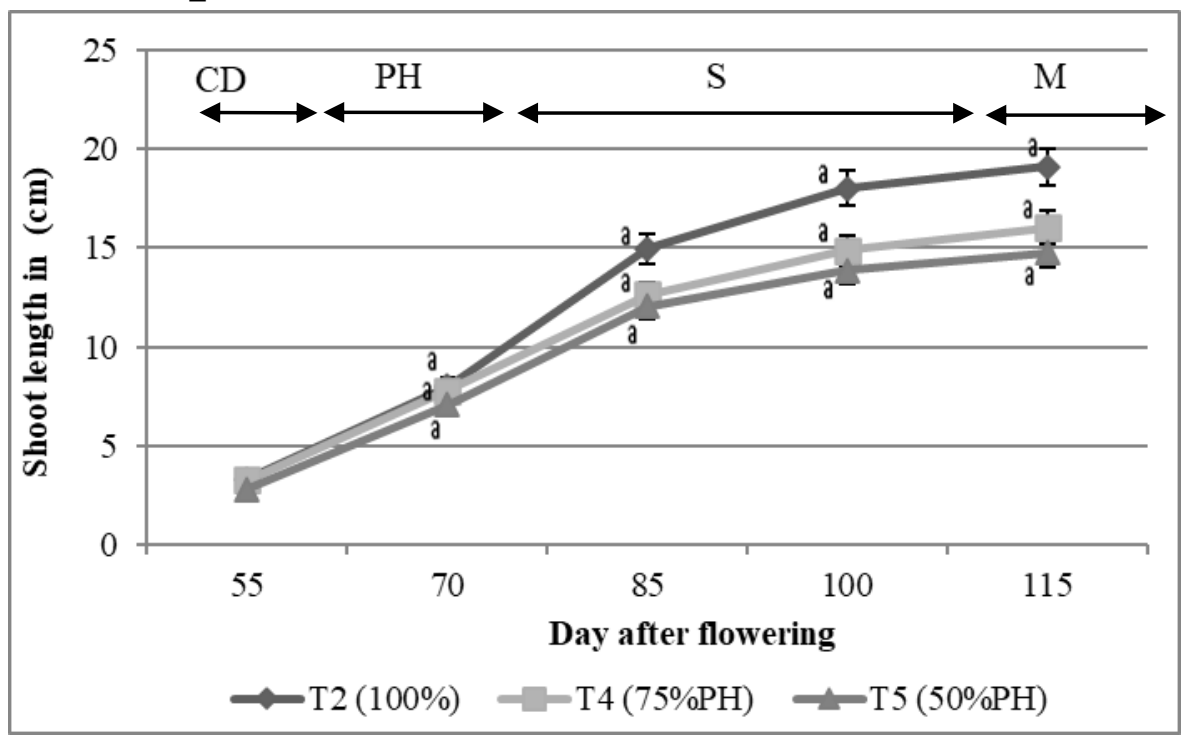

Fig. 6. Effect of Regulated Deficit Irrigation (RDI) on the shoot length during fivemeasurements at $55 ; 70 ; 85 ; 100 \& 115$ days after flowering. The lines represent the standard deviation. The treatments are described in section 2.2.CD: cell division stage; PH: pit hardening stage; S: swelling fruit stage; M: maturity. The different letters indicate significant differences in the corresponding date, according to the SNK test at $\mathrm{P} \leq 0.05$.

\subsection{Production parameters}

\subsubsection{Fruit number/tree}

Our starting point was a number of around 320 fruits per tree after thinning operation, with no significant difference between $\mathrm{T} 1, \mathrm{~T} 2$ and $\mathrm{T} 3$ on the one hand (Table 2), and between $\mathrm{T} 2$, T4 and T5 on the other (Table 3). It is noteworthy that T2 recorded a deviation of 18 fruits/tree from the 320 fruits intended. Whereas T1 and T3 recorded, respectively, only 1 and 4 additional fruit per tree. For RDI treatments, T4 was found to increase by 5 fruits/tree compared to T2, while T5 recorded 6 fewer fruits/tree compared to T2.

\subsubsection{Average yield}

In their $17^{\text {th }}$ year, the trees in the experimental plot achieved a maximum yield of 46.43 T/ha recorded for the T2 control. For the SDI, statistical analysis revealed that irrigation rate has no effect on average yield; and therefore, no significant difference between the T1 treatment resulting in $45.50 \mathrm{~T} / \mathrm{ha}$ and $\mathrm{T} 2$ on the one hand; and T3 reaching $-2.72 \mathrm{~T} / \mathrm{ha}$ lesser than $\mathrm{T} 2$ on the other hand. This makes it possible to say that a $25 \%$ increase or decrease of the irrigation dose compared to the crop water requirements $(100 \% \mathrm{ETc})$ does not affect yields. Similarly, for RDI, the analysis of variance revealed no significant difference between the T2 control and the regulated deficit irrigation treatments $\mathrm{T} 4$ (75\% $\mathrm{PH})$ and $\mathrm{T} 5$ $(50 \% \mathrm{PH})$. In fact, $\mathrm{T} 4$ recorded $+0.93 \mathrm{~T} / \mathrm{ha}$ more than the control treatment, a difference 
that could be due to the number of fruits/tree which was higher for T4 than it was for T2. A non-significant decrease in yield was observed in $\mathrm{T} 5$ treatment compared to $\mathrm{T} 2$, with almost $-3 \%$ less (1.45T/ha).

\subsubsection{Fruit drop rate}

The Benedicte cultivar, subject of this study, is among the varieties that are characterized by fruits dropping off at maturity. To investigate the effect of the irrigation dose on the intensity of this feature, the variation in the number of fruits between thinning and harvesting was monitored. This allowed us to show a clearly significant difference between $\mathrm{T} 1$ and $\mathrm{T} 3$ in the fruit drop rate, in fact, $\mathrm{T} 1$ showed a high trend of fruit falling at maturity, with $13.25 \%$ of fruit loss at maturity, compared to T3, which contributed to losses of around $6.32 \%$. So a shift from $125 \%$ ETc to $75 \%$ ETc might allow the preservation of almost $7 \%$ of the production from this phenomenon. On the other hand, no significant difference has been revealed between $\mathrm{T} 1$ and $\mathrm{T} 2$ or between $\mathrm{T} 2$ and $\mathrm{T} 3$ in terms of fruit loss at maturity. As for RDI, the analysis of variance revealed no significant difference between T2; T4 and T5. However, the T2 control recorded losses of $9.39 \%$, which is $0.77 \%$ and $3.85 \%$ higher than $\mathrm{T} 4$ and $\mathrm{T} 5$ respectively.

\subsubsection{Fruit weight}

Fruit weighting results in the different treatment are presented in table 2 and 3. Compared to the control one, the T3 treatment (SDI) showed no significant difference in terms of fruit weight, T1 also did not show a significant difference from the control. Furthermore, a significant difference was noticed between $\mathrm{T} 1$ and $\mathrm{T} 3$, with $8.7 \%$ additional weight for $\mathrm{T} 1$ compared to T3. As for the RDI, it was found that the fruit weight is insensitive to regulated deficit irrigation at $75 \%$ and $50 \%$ of the requirements in the pit hardening phase.

\subsubsection{Fruit size}

Figure 7 shows the fruit diameter development speed for the three irrigation doses T1(125\%), T2(100\%) and T3(75\%) over fruits development phase; The reference evapotranspiration values are also represented in the same figure. An initial interpretation of the figure allows us to say that the evolution of the fruit diameter in the three treatments $\mathrm{T} 1, \mathrm{~T} 2$ and $\mathrm{T} 3$ followed the same trend during the three stages of fruit development. It is only at the end of the fruit development phase that a difference in growth speed begins to appear between the treatments, putting T1(125\%) fruits in the first place with the highest growth speed, at around $1 \mathrm{~mm} /$ day, followed by T2(100\%) with almost $0.93 \mathrm{~mm} /$ day and lastly $\mathrm{T} 3$ at $0.74 \mathrm{~mm} /$ day rate. This difference in growth speed could have resulted in a significant difference in the final size of the fruit. Indeed, the fruit size at harvest of T1 came in the first position with an average of $76.17 \mathrm{~mm}$, followed by $\mathrm{T} 2$ with $75.17 \mathrm{~mm}$ and $\mathrm{T} 3$ was the last with $73.03 \mathrm{~mm}$. The difference was not significant enough between $\mathrm{T} 1$ and T2 which did not allow to have a significant difference after the statistical analysis, but the difference was clearly significant between $\mathrm{T} 3$ and $\mathrm{T} 2$ on the one hand and T3 and T1 on the other hand. As regards RDI, it was found that the application of a water restriction by $25 \%$ and $50 \%$ in the pit hardening phase did not have a significant effect on the fruit's growth rate or on its final size. It should be noted that the difference in size between T2 and T4 was around $0.38 \mathrm{~mm}$ and between T2 and T5 was $0.82 \mathrm{~mm}$ (fig 8). 
Table 2. Effects of Sustainable Deficit Irrigation (SDI) on yield parameters (average yield, fruit drop rate, fruit weight, fruit size and fruit number/tree) of peach trees (var. Benedict). The treatments are described in Section 2.2. Data represent means \pm standard deviation. The different letters indicate significant differences according to the SNK test at $\mathrm{P} \leq 0.05$.

\begin{tabular}{|l|c|c|c|}
\hline \multicolumn{1}{|c|}{ Parameter } & \multicolumn{3}{|c|}{ Treatment } \\
\hline \multirow{2}{*}{ Fruit number/tree } & $\mathbf{T 1}(\mathbf{1 2 5} \%)$ & $\mathbf{T 2}(\mathbf{1 0 0 \%})$ & $\mathbf{T 3}(\mathbf{7 5 \%})$ \\
\cline { 2 - 4 } & $\mathbf{3 2 1} \pm 40,96 \mathbf{a}$ & $\mathbf{3 3 8} \pm 74,54 \mathbf{a}$ & $\mathbf{3 2 4} \pm 61,79$ a \\
\hline \multirow{2}{*}{ Average yield (T/ha) } & $\mathbf{T 1}(\mathbf{1 2 5} \%)$ & $\mathbf{T 2}(\mathbf{1 0 0 \%})$ & $\mathbf{T 3}(\mathbf{7 5 \%})$ \\
\cline { 2 - 4 } & $\mathbf{4 5 , 5 0} \pm 5,97 \mathbf{a}$ & $\mathbf{4 6 , 4 3} \pm 10,49 \mathbf{a}$ & $\mathbf{4 3 , 7 1} \pm 8,42 \mathbf{a}$ \\
\hline \multirow{2}{*}{ Fruit drop rate (\%) } & $\mathbf{T 1}(\mathbf{1 2 5 \% )}$ & $\mathbf{T 2}(\mathbf{1 0 0 \%})$ & $\mathbf{T 3}(\mathbf{7 5 \%})$ \\
\cline { 2 - 4 } & $\mathbf{1 3 , 2 8} \pm 6,13 \mathbf{a}$ & $\mathbf{9 , 3 9} \pm 3,91 \mathbf{a b}$ & $\mathbf{6 , 3 2} \pm 3,89 \mathbf{b}$ \\
\hline \multirow{2}{*}{ Fruit weight (mg) } & $\mathbf{T 1}(\mathbf{1 2 5 \% )}$ & $\mathbf{T 2}(\mathbf{1 0 0 \%})$ & $\mathbf{T 3}(\mathbf{7 5 \%})$ \\
\cline { 2 - 4 } & $\mathbf{2 3 8 , 8 0} \pm 34,20 \mathbf{a}$ & $\mathbf{2 3 4 , 9 5} \pm 31,07 \mathbf{a b}$ & $\mathbf{2 1 9 , 8 2} \pm 27,76 \mathbf{b}$ \\
\hline \multirow{2}{*}{ Fruit size (mm) } & $\mathbf{T 1}(\mathbf{1 2 5} \%)$ & $\mathbf{T 2}(\mathbf{1 0 0 \%})$ & $\mathbf{T 3}(\mathbf{7 5 \%})$ \\
\cline { 2 - 4 } & $\mathbf{7 6 , 1 7} \pm 3,57 \mathbf{a}$ & $\mathbf{7 5 , 1 7} \pm 3,63 \mathbf{a}$ & $\mathbf{7 3 , 0 3} \pm 3,50 \mathbf{b}$ \\
\hline
\end{tabular}

Table 3. Effects of Regulated Deficit Irrigation (RDI) on yield parameters (average yield, fruit drop rate, fruit weight, fruit size and fruit number/tree) of peach trees (var. Benedict). The treatments are described in Section 2.2. Data represent means \pm standard deviation. The different letters indicate significant differences according to the SNK test at $\mathrm{P} \leq 0.05$

\begin{tabular}{|c|c|c|c|}
\hline Parameter & \multicolumn{3}{|c|}{ Treatment } \\
\hline \multirow{2}{*}{ Fruit number/tree } & T2 (100\%) & T4 (75\% PH) & T5 (50\% PH) \\
\hline & $338 \pm 74,54 \mathrm{a}$ & $343 \pm 59,34 \mathrm{a}$ & $332 \pm 53,85 \mathrm{a}$ \\
\hline \multirow{2}{*}{ Average yield (T/ha) } & $\mathrm{T} 2(100 \%)$ & T4 (75\% PH) & T5 (50\% PH) \\
\hline & $46,43 \pm 10,49 \mathrm{a}$ & $47,36 \pm 8,19$ a & $44,98 \pm 7,66$ a \\
\hline \multirow{2}{*}{ Fruit drop rate $(\%)$} & T2 $(100 \%)$ & T4 (75\% PH) & T5 (50\% PH) \\
\hline & $9,39 \pm 3,91 \mathrm{a}$ & $8,62 \pm 3,85$ a & $5,54 \pm 4,20$ a \\
\hline \multirow{2}{*}{ Fruit weight (mg) } & $\mathrm{T} 2(100 \%)$ & T4 (75\% PH) & T5 (50\% PH) \\
\hline & $234,95 \pm 31,07 \mathrm{a}$ & $231,27 \pm 31,64 \mathrm{a}$ & $224,55 \pm 31,99 a$ \\
\hline \multirow{2}{*}{ Fruit size (mm) } & T2 $(100 \%)$ & T4 (75\% PH) & T5 (50\% PH) \\
\hline & $75,17 \pm 3,63$ a & $74,79 \pm 3,51 \mathrm{a}$ & $74,35 \pm 3,98$ a \\
\hline
\end{tabular}




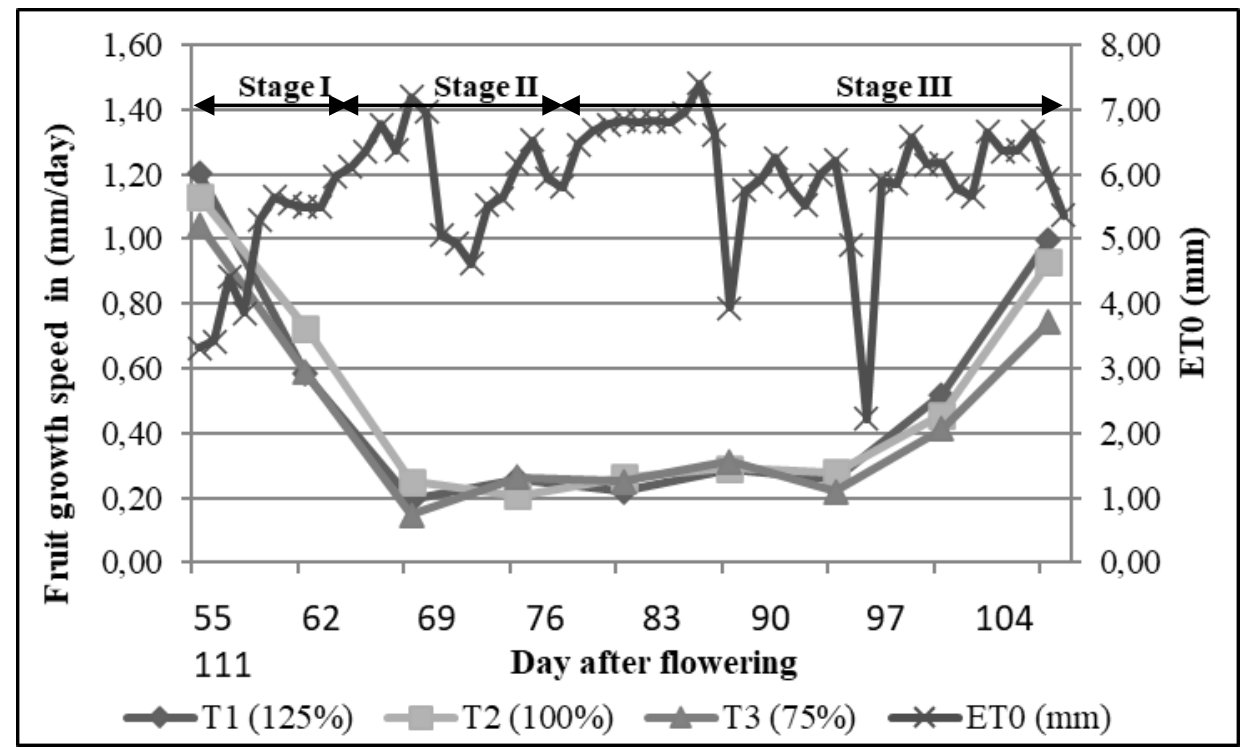

Fig. 7. Effect of Ssustainable Deficit Irrigation (SDI) on fruit growth speed from the $55^{\text {th }}$ day until the $111^{\text {th }}$ day after flowering. Stage I: celle division; Stage II: pit hardening; Stage III: fruit swelling stage. The reference evapotranspiration (ET0). The treatments are described in section 2.2.

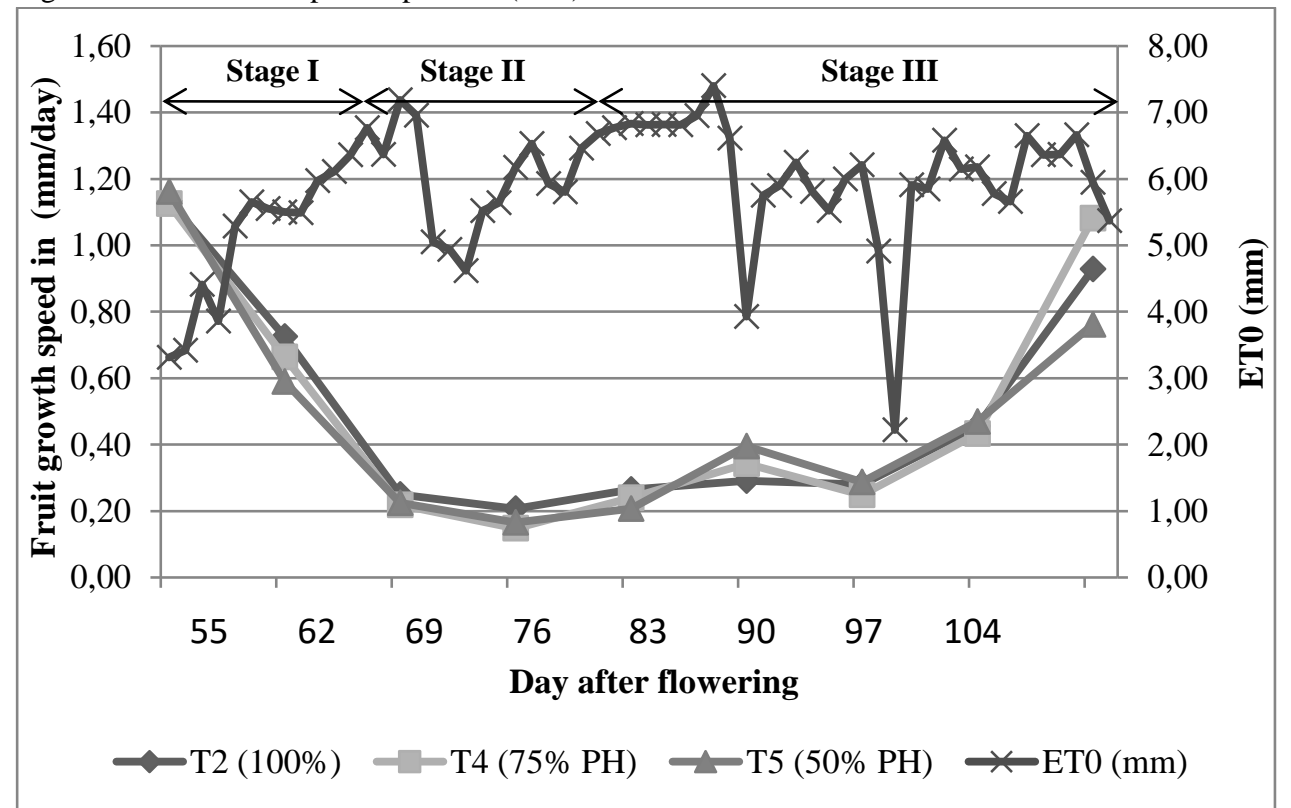

Fig. 8. Effect of Regulated Deficit Irrigation (RDI) on fruit growth speed the $55^{\text {th }}$ day until the $111^{\text {th }}$ day after flowering. Stage I: celle division; Stage II: pit hardening; Stage III: fruit swelling stage. The reference evapotranspiration (ET0). The treatments are described in section 2.2.

\subsection{Quality parameters}

\subsubsection{Sugar content}


Concerning the sugar content of peach fruits, Table 4 shows the effect of the irrigation dose on the ${ }^{\circ}$ Brix content. For the SDI, the results show that reducing the irrigation dose tends to increase the sugar concentration in the fruit at harvest stage. This finding was confirmed by the results of the statistical analysis which showed the presence of a significant difference in the sugar level of the fruit by identifying two homogeneous groups using the StudentNewman and Kleus test at the 5\% threshold. The first group included the T3 treatment $\left(75 \%\right.$ ETc) with an average of $13.42{ }^{\circ}$ Brix, the second group included the other two treatments T2 $\left(100 \%\right.$ ETc) with an average of $12.08{ }^{\circ}$ Brix and T1 $(125 \%$ ETc) with an average of $11.62{ }^{\circ}$ Brix. As for the RDI, the application of a $50 \%$ water restriction during the pit hardening stage led to a significant sugar content increase in the fruit compared to the other treatments. This was confirmed through the results of the statistical analysis which showed the presence of a significant effect of the T5 treatment $(50 \% \mathrm{PH})$ on the fruit sugar content compared to the T2 treatment $(100 \%)$. Whereas the $25 \%$ water restriction, $\mathrm{T} 4 \mathrm{(75 \%}$ $\mathrm{PH})$, did not significantly affect the sugar content of the fruit compared to the T2 control $(100 \%)$.

\subsubsection{Acidity}

Tables $4 \& 5$ summarize the effect of water restriction regime on the fruit's acid content at harvest. The results show that reducing the irrigation amount tends to significantly reduce fruit acidity. In fact, a transition from $125 \%$ ETc to $75 \%$ ETc leads to a $13 \%$ reduction in fruit acidity. However, statistical analysis did not reveal any significant difference between the T3 deficiency treatment (75\% ETc) and the T2 control treatment (100\% ETc). As for the controlled deficit irrigation, the statistical analysis showed no significant effect of water restrictions (during the pit hardening stage) on fruit acidity.

\subsubsection{Firmness}

In Peaches industry, firmness is a key factor of external quality; and plays an important role in the commercial valuation of the final production. In our study, firmness monitoring results at harvest showed that there is no significant effect of SDI treatments on this parameter. However, treatment T3 $(75 \%)$ recorded the highest value $\left(6.05 \mathrm{~kg} / \mathrm{cm}^{2}\right)$, followed by treatments T2 (100\% ETc) and T1 (125\% ETc) with $5.95 \mathrm{~kg} / \mathrm{cm}^{2}$ and 5.93 $\mathrm{kg} / \mathrm{cm}^{2}$ respectively. As for RDI, statistical analysis reported no significant difference between the two water deficient treatments T4 and T5 and the T2 comfort treatment. In fact, the average fruits firmness of the treatment T5 $(50 \% \mathrm{PH})$ was the highest with a value of $6.04 \mathrm{~kg} / \mathrm{cm}^{2}$.

Table 4. Effects of Sustainable Deficit Irrigation (SDI) on Quality parameters (Sugar content, acidity and firmness) and Biochemical parameters (Proline content). The treatments are described in Section 2.2. Data represent means \pm standard deviation. The different letters indicate significant differences according to the SNK test at $\mathrm{P} \leq 0.05$.

\begin{tabular}{|c|c|c|c|}
\hline Parameter & \multicolumn{3}{|c|}{ Treatment } \\
\hline \multirow{2}{*}{ Sugar content $\left({ }^{\circ}\right.$ Brix) } & T1 (125\%) & T2 (100\%) & T3 (75\%) \\
\cline { 2 - 5 } & $\mathbf{1 1 , 6 2 \pm 1 , 0 2}$ b & $\mathbf{1 2 , 0 8} \pm 1,09 \quad$ b & $\mathbf{1 3 , 4 2 \pm} 1,35 \quad$ a \\
\hline Acidity (g of Malic acid/I) & T1 (125\%) & T2 (100\%) & T3 (75\%) \\
\hline
\end{tabular}




\begin{tabular}{|c|c|c|c|}
\hline & $\mathbf{9 , 2 5} \pm 0,78 \mathbf{a}$ & $\mathbf{8 , 7 0} \pm 0,65 \mathbf{a b}$ & $\mathbf{8 , 0 1} \pm 1,10 \mathbf{b}$ \\
\hline \multirow{2}{*}{ Firmness $\left(\mathrm{kg} / \mathbf{c m}^{2}\right)$} & $\mathbf{T 1}(\mathbf{1 2 5} \%)$ & $\mathbf{T 2}(\mathbf{1 0 0 \%})$ & $\mathbf{T 3}(\mathbf{7 5 \%})$ \\
\cline { 2 - 4 } & $\mathbf{5 , 9 3} \pm 0,48$ a & $\mathbf{5 , 9 5} \pm 0,56 \quad \mathbf{a}$ & $\mathbf{6 , 0 5} \pm 0,49 \quad \mathbf{a}$ \\
\hline \multirow{2}{*}{ Proline content $(\mathbf{m m o l} / \mathbf{L})$} & $\mathbf{T 1}(\mathbf{1 2 5} \%)$ & $\mathbf{T 2}(\mathbf{1 0 0 \%})$ & $\mathbf{T 3}(\mathbf{7 5 \%})$ \\
\cline { 2 - 4 } & $\mathbf{0 , 0 6 5} \pm 0,014 \mathbf{b}$ & $\mathbf{0 , 0 9 4} \pm 0,018 \mathbf{b}$ & $\mathbf{0 , 1 4 8} \pm 0,022 \mathbf{a}$ \\
\hline
\end{tabular}

Table 5. Effects of Regulated Deficit Irrigation (RDI) on Quality parameters (Sugar content, acidity and firmness) and Biochemical parameters (Proline content). The treatments are described in Section 2.2. Data represent means \pm standard deviation. The different letters indicate significant differences according to the SNK test at $\mathrm{P} \leq 0.05$.

\begin{tabular}{|c|c|c|c|}
\hline Parameter & \multicolumn{3}{|c|}{ Treatment } \\
\hline \multirow{2}{*}{ Sugar content $\left({ }^{\circ}\right.$ Brix) } & T2 (100\%) & T4 (75\% PH) & T5 (50\% PH) \\
\hline & $\mathbf{1 2 , 0 8} \pm 1,09 \mathbf{b}$ & $\mathbf{1 2 , 1 4} \pm 0,82 \mathbf{b}$ & $\mathbf{1 2 , 7 0 \pm 2 , 1 4 \mathbf { a }}$ \\
\hline \multirow{2}{*}{ Acidity (g of Malic acid/l) } & T2 $(100 \%)$ & T4 (75\% PH) & T5 (50\% PH) \\
\hline & $\mathbf{8 , 7 0} \pm 0,65 \mathbf{a}$ & $\mathbf{8 , 5 6} \pm 0,79 \mathbf{a}$ & $\mathbf{8 , 4 7} \pm 0,78 \mathbf{a}$ \\
\hline \multirow[t]{2}{*}{ Firmness $\left(\mathbf{k g} / \mathrm{cm}^{2}\right)$} & $\mathrm{T} 2(100 \%)$ & T4 (75\% PH) & T5 (50\% PH) \\
\hline & $\mathbf{5 , 9 5} \pm 0,56 \mathbf{a}$ & $\mathbf{5 , 9 6} \pm 0,60 \mathbf{a}$ & $\mathbf{6 , 0 4} \pm 0,55$ a \\
\hline \multirow[t]{2}{*}{ Proline content $(\mathrm{mmol} / \mathrm{L})$} & $\mathrm{T} 2(100 \%)$ & T4 (75\% PH) & T5 (50\% PH) \\
\hline & $\mathbf{0 , 0 9 4} \pm 0,018 \mathbf{b}$ & $\mathbf{0 , 1 1 6} \pm 0,025 \mathbf{b}$ & $\mathbf{0 , 1 8 7} \pm 0,016 \mathbf{a}$ \\
\hline
\end{tabular}

\subsection{Biochemical parameters}

\subsubsection{Proline content}

Proline accumulation is often reported as a consequence of water and/or salt stress. The high accumulation of proline in the leaves could be the result of a decrease in its oxidation and/or a reduction in its use in protein synthesis. Similarly, hydrolysis of proline-rich proteins and/or activated synthesis of this amino acid would lead to its accumulation in cells[23]. The results illustrated in tables 4 and 5 shows that water stress induced a remarkable accumulation of proline in peach leaves. Indeed, between T1, T2 and T3, proline synthesis was negatively correlated with irrigation dose. Similarly, for RDI, T5 was found to be more stressed than T4 and T2.

\subsection{Water use efficiency}

Agronomic water use efficiency (WUE) is an important index that measures the productivity of provided water amount from the perspective of irrigation efficiency. The calculation formula is as follows: WUE = Yield in $\mathrm{kg} /$ amount of water applied in $\mathrm{m} 3$.

In this study, WUE was improved by applying treatment deficits T3, T4, and T5 leading to respectively: $946 \mathrm{~m} 3 / \mathrm{ha}, 124 \mathrm{~m} 3 / \mathrm{ha}$, and $248 \mathrm{~m} 3 / \mathrm{ha}$ water savings (table 6). Compared to the control treatment, the T3 treatment (75\%), which had no effect on fruit yield, improved the WUE by 16\%; and the Regulated Deficit Irrigation (RDI) treatments increased the WUE by $6 \%$ and $2 \%$ respectively for T4 (75\%) and T5 (50\%). It should be noted that the 
increase in T4 in terms of yield allowed it to have higher water use efficiency than T5 where $50 \%$ less water was supplied compared to the control T2 (100\%).

Table 6. Water use efficiency (WUE) of T1 (125\%), T2 (control, 100\%), T3 (75\%, SDI), T4 (75\%, RDI) and T5 (50\%, RDI).

\begin{tabular}{|c|c|c|c|}
\hline Traitement & $\begin{array}{l}\text { Average yeild } \\
\text { (Kg/ha) }\end{array}$ & $\begin{array}{l}\text { Amount of water } \\
\text { applied (m³/ha) }\end{array}$ & $\begin{array}{c}\text { Water use } \\
\text { efficiency }\left(\mathrm{Kg} / \mathrm{m}^{3}\right)\end{array}$ \\
\hline T1 (125\%) & 45502 & 6002 & 7,58 \\
\hline T2 $(100 \%)$ & 46433 & 5057 & 9,18 \\
\hline T3 (75\%) & 43712 & 4111 & 10,63 \\
\hline T4 (75\% PH) & 47356 & 4933 & 9,60 \\
\hline T5 (50\% PH) & 44984 & 4809 & 9,35 \\
\hline
\end{tabular}

\section{Discussion}

\subsection{Vegetative growth}

The applied water deficit, whether SDI (T3; 75\%ETc) or RDI (T4 andT5; 75\% and $50 \% \mathrm{ETc}$ ) in pit hardening phase did not affect neither the vegetative growth of the mixed shoots (the organs carrying fruit during the season), nor the young shoots (the origin of future mixed shoots). This allows us to say that for peaches, the development of these organsis insensitive to a $25 \%$ reduction in water supply during the entire growth cycle (T3); or a water restriction in the stone hardening phase equivalent to $25 \%$ or $50 \%$ of the crop water requirements(T4 and T5 respectively). Furthermore, it was remarkable that among the three deficit treatments (T3, T4 and T5), the RDI treatments (T4 and T5) were the closest in terms of vegetative growth behavior to the T2 control. On the other hand, it was found that despite an increase in intake to $125 \%$ (T1) there was no increase or acceleration of the growth of mixed twigs and shoots compared to the control (100\% ETc).

These conclusions are in contradiction with other results found by several authors in the same climate or in different climates. Indeed,Razouk et al., [12]adopted similar water restriction level as in this study (75\% and 50\% in pit hardening stage) and in almost equivalent climate conditions (Fez-Meknes region; Morocco) and found a significant decrease in shoot growth compared to the control. This can be explained by the climate effect throughout the growing season which intervenes in terms of evapotranspirationdemand ET0 and rainfall (the two experiments were not carried out in the same year). In different climates (France and Spain) and under severe water restriction, $(\mathrm{Li}$, et al., and Sotiropoulos et al., $[11,13]$ irrigated respectively $33 \%$ ETc and $35 \%$ ETc during the pit hardening and $100 \%$ during the rest of the cycle and both reported that the applied water deficit has significantly reduced the growth of mixed shoots and the development of shoots. This difference between the results of present study and those of $\mathrm{Li}$ et al [11] and Sotiropoulos et al.,[13]may be related to the stress threshold applied during the stone hardening. We believe that the selected stress threshold in this study was not as severe as in those of $\mathrm{Li}$, et al and Sotiropoulos et al $[11,13]$; which probably allowed to highlight the growth difference between these deficient treatments and the control. This leads to the conclusion that the more severe the water stress in the pit hardening phase, the 
more apparent the decrease in vegetative growth is when compared to a $100 \%$ ETc treatment.

As for SDI, Abrisqueta et al., in Spain[17], and by providing 50\% of the water needs throughout the fruit growth cycle, found a significant effect of deficit irrigation on stem growth and pruning weight. Whereas in our experience, SDI $(\mathrm{T} 3 ; 75 \%)$ had no effect on tree vegetative growth.

\subsection{Production}

It was concluded in this study that the yield was insensitive to water regime changes. In other terms, the water deficit induced by the three treatments T3 (75\%; SDI); T4 (75\% PH; RDI) and T5 (50\% PH; RDI) did not significantly affect the yield. Similarly, the increase in water intake to $125 \%$ of the evapotranspiration needs did not increase the yield.

Furthermore, a significant difference was concluded for the fruit average weight and size at harvest between SDI treatment $(\mathrm{T} 3 ; 75 \%)$ on the one hand and both $\mathrm{T} 1$ and $\mathrm{T} 2$ on the other hand. Applying water restriction has been revealed as tending to decrease both fruits weight and size; This result may not be encouraging for farmers interested in managing fruit size to comply with market specifications. However, it should be noted that the reduction in fruit size in $\mathrm{T} 3$ compared to $\mathrm{T} 1$ and $\mathrm{T} 2$ only began to appear at the end of the swelling phase. This leads us to consider a reduction in the water restriction level applied towards the end of this phase, or even to reduce this level throughout the cycle and examine whether the difference in fruit size compared to the control is still persisting. On the other hand, it should be noted that the RDI treatments T4 and T5 did not show any significant difference with $\mathrm{T} 2$ in terms of yield, size or average fruit weight.

In addition, and for Regulated Deficit Irrigation (RDI), many studies have also shown that deficit irrigation during Phase II does not affect production. Among others, a 3years study about the "Andross " variety has shown that deficit irrigation by $35 \%$ ETc during the pit hardening phase has no effect on fruit production[15]. This finding was again confirmed by Sotiropoulos et al. [13], in a study carried out in Greece on the variety "A-37" with a water deficit of $35 \%$ ETc. In this study, authors reported that the tested irrigation regime had no effect on productivity, and on both fresh and dried fruit weight. Moreover, the size of "Merrill Sundance" variety' fruits at harvest was not affected by a water deficit of $66 \%$ ETc in France [11].

Nevertheless, other authors have found different responses of peaches to irrigation restrictions during fruit growth phase II.In a study carried out in Morocco revealed a significant reduction in yield and fruit size at harvest for an irrigated treatment at $50 \%$ of evapotranspiration requirements[12]. Similarly, a stady in spane showed that restriction of irrigation (by 60\% ETc) during pits hardening of untinned peaches of the "Andross" variety intended for the processing industry affected stem growth, total yield and fruit size[16]. These different behaviors could be due to other factors such as fruit load, variety, climatic conditions and soil water retention properties.

Concerning sustainable deficit irrigation (SDI), and in contradiction with our results, all the studies we have reviewed agree that for peaches, sustainable deficit irrigation (SDI) significantly reduces the yield. Indeed, in Tunisia, yield of the late production variety "Carnival" seems to be linked to irrigation regimes, and thus sustainable deficit irrigation (SDI) at 33\% ETc leads to significant water savings (33\%) but a yield reduction of $14 \%$ [19].Once again in Spain and on an early production variety, a water restriction of half of the needs considerably penalizes peach yields[17]. The discrepancy between our results from Abrisqueta and Ghrab can be explained by the fact that the water restriction in our 
study was the lowest compared to those of these studies (25\% vs. 67\%; 50\%); which did not allow, probably, a difference in yield to occur. Another explication could be linked to the irrigation approach we used in this study. The high frequency in irrigation application per day could increase the water use efficiency as well as the nutrient use efficiency. It is well known that irrigation water management and humidity in soil are key factors to succeed in irrigation management. In our case, to satisfy the crop water requirements, the number of irrigations per day was between one to six irrigations according to the Readily Available Water (RAW) which corresponds to the amount of water that a soil can hold in the effective root depth. Moreover, the considered irrigation triggering percentage was $(5 \%)$ leading to high frequency in irrigation.

As for fruit weight, Crisosto et al., [18]restricted the irrigation supply by $50-75 \%$ ETc to 'O Henry' variety plantations in California and highlighted a reduction in fruit weight; confirming our results on the effect of $\mathrm{T} 3$ on fruit weight.

For the rate of fruit falling at maturity, which is typical for the "Benedicte" variety, no significant difference of this percentage was recorded among the deficit irrigated treatments T3, T4 and T5 compared to T2, but the difference is clearly noticeable between (T2; T3; T4; T5) on the one hand and T1 on the other hand. However, Sotiropoulos et al, [13], found, under severe water stress (35\% ETc) during stone hardening, a significant decrease in this percentage compared to a treatment irrigated at $100 \%$ crop evapotranspiration.

\subsection{Fruit quality}

Several studiesagreed with our findings and confirm that water stress during the second phase of fruit development induces an increase in soluble sugar levels TSS[11, 12, 13]. However, it has no effect on firmness according to Sotiropoulos et al., [13] works. In addition, it reduces acidity according to a Moroccan study[12].

Similarly, for sustainable deficit irrigation (SDI), and in harmony with our results, the majority of studies agree that the level of total sugars increases in the fruits of trees exposed to SDI whereas titratable acidity decreases[11, 18, 24].

\subsection{Agronomic Water use efficiency}

It is clear that to achieve the same performance as the control treatment, the more water is saved compared to the control treatment, the more efficient the water use. In our experience and due to non-significant performance differences between treatments, the water use efficiency of the different treatments did not follow the same ranking as the water saved. In fact, the SDI T3 treatment (75\%) resulted in a water saving of $18.70 \%$ compared to the amount of water supplied for the control, which is a saving of $946 \mathrm{~m}^{3} / \mathrm{ha}$ compared to the control, and with an average efficiency of $43.7 \mathrm{t} / \mathrm{ha}$, the water use efficiency (WUE) was $10.63\left(\mathrm{~kg} / \mathrm{m}^{3}\right)$. As per RDI, and in terms of water saving, we found T5 $(50 \% \mathrm{PH})$ in first place with $4.90 \%$ water saved compared to the control T2 (100\%) (248 m3/ha less than the control), followed by T4 $(75 \% \mathrm{PH})$ with $2.45 \%(124 \mathrm{~m} 3 / \mathrm{ha})$ compared to the control. However, in terms of yield, T4 came first with $47.35 \mathrm{t} / \mathrm{ha}$ compared to T5, which could only reach $44.98 \mathrm{t} / \mathrm{ha}$. The fact of having a low water saving, but a high potential yield, allowed T4 to be in first place in terms of water use efficiency with $9.60\left(\mathrm{~kg} / \mathrm{m}^{3}\right)$ compared to $\mathrm{T} 5$, which recorded $9.35(\mathrm{~kg} / \mathrm{m} 3)$ of water productivity.

On the other hand, T1 is found to be the treatment with the maximum amount of water applied among all the treatments, but without any advantage in terms of efficiency 
compared to the control. This classifies it as the most inefficient treatment in terms of water use efficiency, with only $7.58\left(\mathrm{~kg} / \mathrm{m}^{3}\right)$.

In an experiment carried out in Spain[25], Tapia Vargas et al., tested "Flordestar" variety behavior under SDI $(50 \%$ ETc) and achieved showed a water use efficiency of around $2.7 \mathrm{~kg} / \mathrm{m}^{3}$ compared to the control (120\% ETc) $2.1 \mathrm{~kg} / \mathrm{m}^{3}$. The difference between the WUE in our experience and theirs is due to the difference between the cultivars ("Flordestar" is a late production variety while "Benedicte" is a seasonal variety); as well as a difference in rainfall during the growing cycle and in yields achieved; which will result in a different water use efficiency.

\section{Conclusion}

This study had as an objective to assess the response of commercial plantation of peaches under Mediterranean climate conditions to various irrigation restrictions. Based on the evolution of the parameters monitored under the water restrictions conditions, it is concluded that a restriction of $25 \%$ of the crops water requirement treatment gavea good compromisein peach tree irrigation, allowing a net improvement in water use efficiency, fruit quality without any significant reduction in yield or vegetative growth. In addition, this water regime has the disadvantage of reducing fruit size, making it unattractive to farmers targeting markets of large size fruits. On the other hand, the regulated deficit irrigation treatmentsT4 and T5 showed similar performance to the control treatment in terms of yield and size. Therefore, it is likely that the negative effects of the T3 treatment on the final fruit size can be reduced by combining sustainable deficit irrigation with regulated deficit irrigation during pit hardening;therefore, it is recommended to integrate this irrigation program as a treatment in future studies to confirm this hypothesis.

\section{Funding}

This work was supported by Moroccan Ministry of Agriculture, Maritime Fisheries, Rural Development and Water and Forestry. It's a part of the research project Competitive Research Development and Extension Mechanism (MCRDV). The project consists in the installation of a modern field platform dedicated to research and development of smart irrigation management in the region of Fez-Meknes.

\section{Acknowledgements}

This study was conducted by the research unit SPEC-trum (Sol-Plante-Eau-Climat Continuum) within the National School of Agriculture of Meknes (ENAM) in Morocco. The authors gratefully acknowledge the Louata administration staff and in particular to Pr. Ait Houssa Abdelhadi and Mr. Hadri karim for their significant interest and technical support, and for their efforts to ensure the projects progression in the best conditions. The authors also wish to thank the student Ait Ijja Sara for her valuable contribution during her final engineering project. 


\section{References}

1. Ragab, prudhomme. Impact du changement climatique sur les régimes hydrologiques des fleuves côtiers Libanais, 3ème conférence internationale sur les "Ressources en Eau dans le Bassin Méditerranéen”, WATMED3, Tripoli, Liban, Novembre, (2002).

2. J.Van Schilfgaarde. Agric. Water Manag. 25, 203-219 (1994).

3. M.M .Jellali, Développement des ressources en eau au Maroc. Direction Général de l'Hydraulique, Rabat, Maroc.(1997)

4. A. Bouaziz, K. Belabbes. H T E, 32, 57-72. (2002)

5. M. Pascual, J.M. Villar, J. Rufat, Agric. Water Manag. 164, 253-266.(2016).

6. J.M. Abrisqueta, O. Mounzer, S. Álvarez, W. Conejero, Y. García-Orellana, L.M. Tapia, J. Vera, I. Abrisqueta, M.C. Ruiz-Sánchez, Agric. Water Manag. 95, 959-967. (2008).

7. M. Guizani, S. Dabbou, S. Maatallah, G. Montevecchi, H. Hajlaoui, M. Rezig, A.N. Helal, S. Kilani-Jaziri. Agric. Water Manag. 217, 81-97. (2019).

8. O. Forey, A. Metay, J. Wery. Eur. J. Agron. 81, 106-116. (2016).

9. J.M. Faci, E.T. Medina, A. Martínez-Cob, J.M. Alonso, Agric. Water Manag. 143, 102112. (2014).

10. M.H. Behboudian, John Wiley, Researchgate, 38, 149 - 189. (2011).

11. S.H. Li, J.G. Huguet, Schoch, P.G., P. Orlando,H S, 64, 5. (1989).

12. R. Razouk, J. Ibijbijen, A. Kajji, M. Karrou, A.J.P.S, 4, 561-570.(2013).

13. T. Sotiropoulos, D. Kalfountzos, I. Aleksiou, S. Kotsopoulos, N. Koutinas, Sci. Agric. 67, 164-169. (2010).

14. X. Vallverdú, J. Girona, G. Echeverría, J. Marsal, M.H. Behboudian, G. Lopez, Sci. HORTSCI 47, 656-659. (2012).

15. J. Girona, M. Gelly, M. Mata, A. Arbonès, J. Rufat, J. Marsal, Agric. Water Manag. 72, 97-108. (2005).

16. X. Domingo, A. Arbonés, J. Rufat, M. Pascual, J.M. Villar, Acta Hortic. 213-220. (2011).

17. I. Abrisqueta, L. Tapia, W. Conejero, M. Sanchez-Toribio, J. Abrisqueta, J. Vera, M.C. Ruiz-Sánchez, J. Agric. Res. 8. (2010).

18. C.H. Crisosto, R.S. Johnson, J.G. Luza, G.M. Crisosto, HortScience,29, 11691171.(1994).

19. M. Ghrab, R. Zitouna, M. Mimoun, M. Masmoudi, N. Ben Mechlia, Biol. Agric. Hortic. 29, 29-37. (2013).

20. FAO-56, Chapter 6 - ETc - Single crop coefficient $(K c)$ [WWW Document]. URL http://www.fao.org/3/X0490E/x0490e0b.htm (accessed 4.9.20).

21. Penman. Estimation de l'évaporation - Penman - 1956 - Eos, Transactions American Geophysical Union. Wiley Online Libr.

22. L.S. Bates, R.P. Waldren, I.D. Teare, P .S.39, 205-207. (1973).

23. L. Ben Khaled, A. Gõmez, M. Honrubia, A. Oihabi, Agro23, 553-560. (2003).

24. H. Engin, F. Şen, G. Pamuk, Z. Gökbayrak, Crop Hortic. Sci. 38, 39-46. (2010).

25. M. Tapia Vargas, A. Larios Guzmán, I. Abrisqueta Villena, O. Mounzer, J. Vera Muñoz, J.M. Abrisqueta García, M.C. Ruiz Sánchez, Rev. Fitotec. Mex. 33, 89-93.( 2010). 